\title{
KAJIAN SPEKTRA IR DAN AAS LEMPUNG TERPILAR-Fe
}

\author{
Pangoloan Soleman Ritonga
}

\author{
Jurusan Pendidikan Kimia, Fakultas Tarbiyah dan Keguruan UIN SUSKA Riau \\ Emaisolemanriau@yahoo.co.id
}

\begin{abstract}
It has been successfully synthesized a new pillared clay adsorbent by using natural bentonite from the Kecamatan Tulakan Pacitas East Java. The synthesis was carried out by intercalation methode by mixing benzalkonium chloride surfactant solution and precursor solution of iron chloride into natural bentonite solution, then the resulted solid phase was calcined at $400^{\circ} \mathrm{C}$. The natural bentonite and the adsorbent of pillared clay were characterized by using infra red spectrosphotometer. The iron oxide content was determined by using atomic absorption spectroscopy. It has been concluded that pillarization proses increased the iron oxide content up to five time depending on the mole ratio of iron and cation exchange capacity (CEC) value of natural bentonite. From infra red spectra, it has been concluded that surfactant intercalation into inter layer space can be observed by using peak at 2925.8 and $2852.5 \mathrm{~cm}^{-1}$, while the iron oxide pillared is not observed.
\end{abstract}

Key words: Lempung, Pillarisasi, Interkalasi, Spectrophotometry IR, AAS

\section{PENDAHULUAN}

Lempung bentonit merupakan mineral lempung dengan kandungan utama monmorillonit kurang lebih $85 \%$. Lempung tersusun dari mineral alumina silikat yang mempunyai struktur kristal berlapis dan berpori. Lempung bentonit mempunyai kemampuan mengembang (swellability) karena ruang antar lapis (interlayer) dapat mengakomodasi ion-ion atau molekul dengan ukuran tertentu.

Menurut Grim (1968) terdapat dua unit penyusun yang terlibat dalam kisi-kisi atom pada sebagian besar mineral lempung. Satu unit tersusun dari oksigen atau hidroksida dengan alumunium, besi atau magnesium yang terkoordinasi dalam sistem oktahedral. Penggabungan dari unit-unit oktahedral ini dapat membentuk struktur lapis oktahedral seperti terlihat pada gambar 1 .
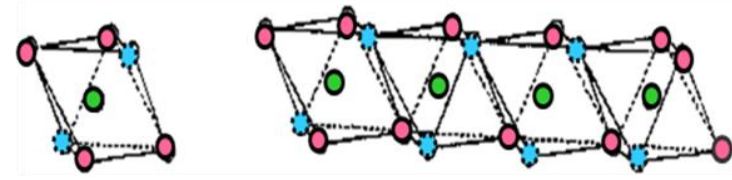

O OKSIGEN $\because$ HIDROKSI

\section{Gambar 1. Unit Oktahedral}

Sedangkan unit pembangun yang lain adalah sistem tetrahedral dari silikon dengan oksigen atau hidroksi. Rangkaian unit-unit tetrahedral ini juga dapat membentuk struktur lapis tetrahedral seperti terlihat pada gambar 2 .

Diantara lapisan terdapat kation-kation yang berfungsi menyeimbangkan muatan negatif yang ada pada bidang lapisnya.

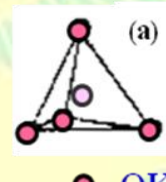

(a)

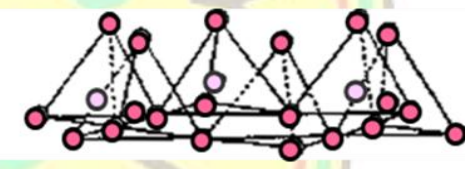

○ OKSIGEN

O SILIKON

\section{Gambar 2. Unit tetrahedral}

Pengelompokan lempung dapat didasarkan atas struktur dan komposisinya (Pinnavaia, 1983). Berdasarkan strukturnya lempung dibagi menjadi 3 golongan yaitu: kristalin (crystalline minerals), amorf (amorphous) dan campuran (mixed layered). Sementara itu mineral kristalin dibedakan menjadi mineral berlapis (layered mineral) dan mineral berserabut (fibrous minerals). Menurut Theng (1977), berdasarkan perbandingan struktur tetrahedral dan oktahedralnya, mineral berlapis dibedakan menjadi 3 yaitu: (1). mineral tipe 1:1, mineral yang terdiri dari satu lapisan oktahedral dan satu lapisan tetrahedral, misalnya kaolin dan sepentin, (2). mineral tipe 2:1, mineral yang 
terdiri dari dua lapisan oktahedral dan satu lapisan tetrahedral, misalnya monmorillonit, mika dan vermikulit, (3). mineral tipe 2:1:1, mineral yang merupakan jenis 2:1 dengan satu lapisan oktahedral tambahan yang tersusun berselang seling, misalnya klovit. Dalam kelompok mineral tersebut, monmorillonit adalah kelompok mineral yang paling menarik karena kemampuannya untuk mengembang (swelling) dan mempunyai kapasitas penukar ion yang tinggi sehingga mampu mengakomodasi kation antar lapisnya dalam jumlah besar (Ogawa, 1992; Wijaya 2000). Struktur montmorillonit dapat dilihat pada gambar 3.

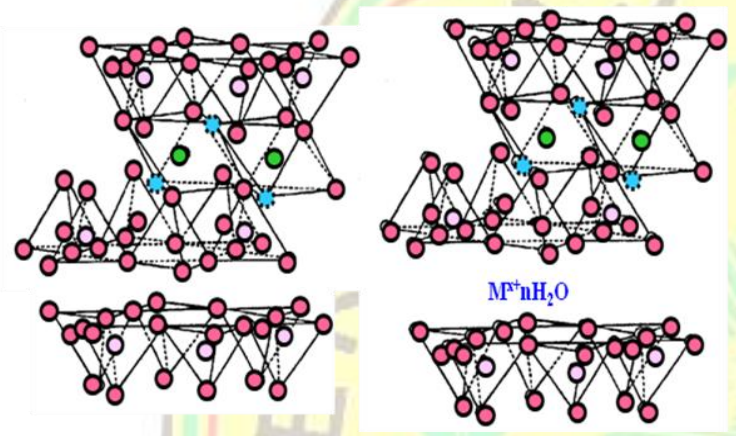

Gambar 3. Struktur Montmorillonit

Lempung sangat berguna untuk dipakai pada bidang katalis, adsorpsi dan pertukaran kation, tetapi mempunyai kelemahan yaitu rusaknya struktur lapis dan hilangnya porositas karena pemanasan pada suhu tinggi (Cool dan Vansant, 1998). Hal tersebut dicoba diatasi dengan proses penyisipan ion atau molekul ke dalam interlayer yang dikenal dengan interkalasi. Pemanasan interkalat akan menghasilkan pillar sehingga proses ini lebih dikenal dengan proses pillarisasi.

Pilarisasi dapat dilakukan dengan menginterkalasikan polikation hidroksi terhadap lempung, selanjutnya dikalsinasi sehingga membentuk pilar-pilar oksida logam (Yang dkk., 1992). Berbagai macam kation dapat digunakan sebagai agen pemilar antara lain ion-ion alkyl ammonium, kation amina bisiklis dan beberapa kation kompleks seperti kelat serta kation hidroksi logam polinuklir dari Al, Zr, Ti, Fe dan lain-lain (Clearfield,1992; Yang dkk., 1992).
Hasil penelitian tersebut menunjukkan bahwa lempung bentonit yang telah terpilar memiliki beberapa kelebihan, antara lain stabilitas termal yang lebih tinggi, volume pori dan luas permukaan yang lebih besar. Adanya sifat unggul dari lempung terpilar menjadikan material tersebut potensial untuk digunakan sebagai adsorben.

Para peneliti telah mengembangkan suatu metode baru dalam sintesis lempung terpilar yaitu interkalasi surfaktan ionik ke dalam rongga antarlapis lempung. Penambahan surfaktan ini bertujuan untuk membuka rongga pada antar lapis lempung sehingga mudah untuk diinterkalasi lebih lanjut dengan kation logam.

Pada penelitian ini surfaktan yang digunakan adalah benzal konium klorida dan sebagai agen pemilarnya yaitu besi klorida, karena benzyl konium klorida dan besi merupakan surfaktan dan logam yang murah dan mudah didapatkan.

Rightor, Tzou dan Pinnavaia (1991) melaporkan, pemilaran dengan oksida besi akan menghasilkan lempung terpilar dengan basal spacing sampai $29 \AA$ Á dengan luas permukaan $350 \mathrm{~m}^{2} / \mathrm{g}$. Hal ini akan meningkatkan daya adsorpsi lempung jika dibandingkan dengan lempung alam yang hanya memiliki luas permukaan $70-100 \mathrm{~m}^{2} / \mathrm{g}$. Dengan adanya surfaktan diharapkan akan mampu meningkatkan porositas serta luas permukaannya dibandingkan dengan lempung terpilar tanpa surfaktan.

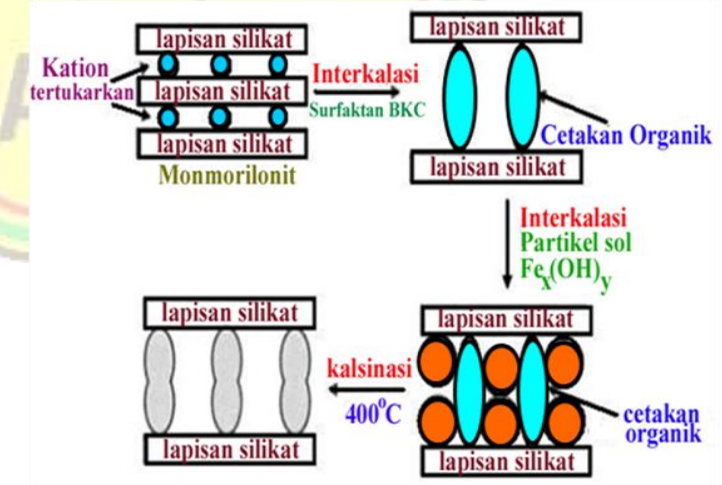

Gambar 4. Proses Pillarisasi

Seperti yang dilaporkan oleh Pinnavaia dkk (1998), lempung terpilar silika yang disintesis dengan menggunakan cetyltrimethylammonium 
bromide (CTMA) sebagai agen templat dan tetraethyl orthosilicate (TEOS) sebagai agen pemilar mempunyai basal spacing antara 2,5-7,5 Á dan luas permukaan spesifiknya antara 400$900 \mathrm{~m}^{2} / \mathrm{g}$. Pada tahun 2001, Kwon dkk. melaporkan lempung terpilar silika yang disintesis dengan menggunakan dodesilamin sebagai agen templat dan TEOS sebagai agen pemilar mempunyai luas permukaan spesifik antara 403-577 m²/g. Polverejan dkk. (2000) mensintesis lempung terpilar silaka dengan luas permukaan spesifik antara $800-920 \mathrm{~m}^{2} / \mathrm{g}$, jarak basal spacing antara 33-35 $\AA$ dan volume pori $0,38-0,44 \mathrm{~cm}^{3} / \mathrm{g}$. Keberhasilan interkalasi ke dalam struktur lempung bentonit diharapkan menjadikan lempung bentonit sebagai pengadsorp (penyerap) pengotor yang efektif

\section{METODE PENELITIAN}

1. Pembuatan Larutan Pemilar

Larutan pemilar polikation $\mathrm{Fe}$ dibuat dengan melarutkan $\mathrm{FeCl}_{3} .6 \mathrm{H}_{2} \mathrm{O}(\mathrm{BM}=270,30 \mathrm{~g} / \mathrm{mol})$ dalam akuades sehingga konsentrasi larutan menjadi $0,2 \mathrm{M}$, kemudian dihidrolisis dengan larutan $\mathrm{NaOH} 0,1 \quad M$ secara perlahan-lahan sampai rasio $\mathrm{OH} / \mathrm{Fe}^{3+}=2$. Larutan ini diaduk sampai homogen selanjutnya didiamkan (aging) selama 24 jam pada temperatur kamar. Jumlah larutan pemilar yang dibuat sesuai dengan kajian variasi rasio mmol Fe: KTK lempung yakni: 1; 7; 13 dan 19.

\section{Pembuatan Suspensi Lempung \\ Bentonit}

Sampel lempung bentonit pada poin-1 ditimbang sebanyak 20 gram dan dilarutkan dalam $1000 \mathrm{ml}$ akuades atau dengan perbandingan $2 \%(\mathrm{~b} / \mathrm{v})$. Larutan ini kemudian diaduk selama 24 jam pada suhu kamar. Dibuat lima suspensi sesuai dengan kajian variasi mmol Fe: KTK lempung.

\section{Proses interkalasi dan Pilarisasi}

Suspensi yang telah disiapkan pada III.2.3 ditambahkan larutan agen templat benzalkonium klorida sebesar; $1 \%$ (1ml bkc/100 ml aguades); $5 \% \quad(5 \mathrm{ml}$ bkc/100 $\mathrm{ml}$ aguades $)$ dan
$10 \%$ (10 ml bkc / $100 \mathrm{ml}$ aguades) untuk masingmasing perlakuan lalu diaduk selama 6 jam. Kemudian ditambahkan larutam pemilar dari poin 2 sedikit demi sedikit dan diaduk selama 24 jam. Hasil padatan disaring dan dicuci dengan akuades hingga bebas ion $\mathrm{Cl}^{-}$(uji negatif terhadap $\mathrm{AgNO}_{3}$ ). Padatan ini dikeringkan dalam oven pada suhu $100-110{ }^{\circ} \mathrm{C}$ selama 5 jam, selanjutnya digerus, diayak.dan dikalsinasi pada $400{ }^{\circ} \mathrm{C}$ selama 5 jam.

\section{Penentuan Gugus Fungsional}

Sampel yang dianalisis sebanyak lebih kurang 1 mgr digerus dan dihomogenkan dengan $100 \mathrm{mgr} \mathrm{KBr}$ dengan cara ditekan menggunakan alat vibtrating mill dengan tekanan sebesar 8-9 ton sehingga membentuk pelet tipis yang transparan. Pelet ini kemudian diletakkan didalam sel instrumen spektrofotometer FTIR-8201 PC Shimatzu dan dianalisis. Analisis dilakukan terhadap sampel lempung alam dan lempung.

\section{Penentuan kadar Fe}

Siapkan larutan standar $\mathrm{Fe}$ dengan konsentrasi $0 ; 2,5 ; 5 ; 10 ; 15$ dan 20 ppm. Diukur absorbansi dari masing-masing larutan standar dan larutan sampel. Dibuat kurva absorbansi versus konsentrasi dan tentukan konsentrasi Fe dalam sampel dengan/regresi linear.

\section{HASIL DAN PEMBAHASAN}

\section{Analisis menggunakan spektro}

\section{fotometer inframerah}

Analisis selanjutnya dilakukan dengan spektroskopi inframerah untuk mengetahui jenis vibrasi antara atom-atom dalam mineral lempung alam. Analisis dilakukan pada daerah bilangan gelombang 400-4000 $\mathrm{cm}^{-1}$ karena biasanya spektra yang karakteristik akan muncul pada daerah tersebut. Hasil analisis dengan spektrofotometer inframerah terhadap lempung alam disajikan dalam gambar 5 . 


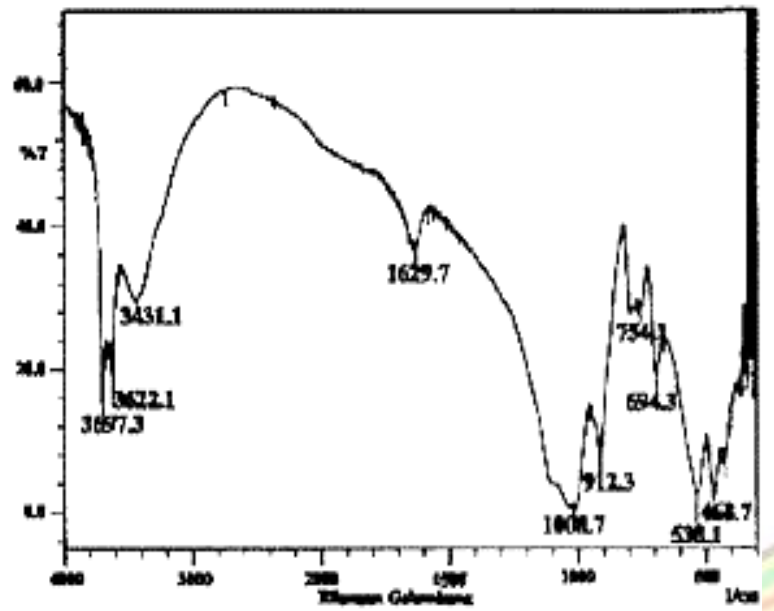

Gambar 5. Spektra inframerah lempung alam

Dari gambar 5 terlihat bahwa lempung alam mempunyai puncak serapan pada daerah bilangan gelombang 468,$7 ; 538,1 ; 694,3 ; 754,1$; 912,$3 ; 1008,7 ; 1629,7 ; 3431,1 ; 3622,1$ dan $3697,3 \mathrm{~cm}^{-1}$. Daerah $400-1200 \mathrm{~cm}^{-1}$ dinamakan juga daerah sidik jari (finge print region). Puncak-puncak yang muncul pada daerah ini anatara lain 1008,$7 ; 912,3 ; 754,1 ; 694,3 ; 538,1$; 468,7; dan $426,2 \mathrm{~cm}^{-1}$. Puncak serapan yang paling tajam pada daerah $1008,7 \mathrm{~cm}^{-1}$ adalah karakteristik vibrasi ulur dari Si-O. Hal ini diperkuat oleh Farmer dan Russell (1964) yang melaporkan bahwa puncak serapan untuk montmorillonit Wyoming (Amerika Serikat) muncul pada bilangan gelombang $1048 \mathrm{~cm}^{-1}$. Sedangkan Flanigen et.al (1971) menyatakan serapan kuat pada daerah $950-1250 \mathrm{~cm}^{-1}$ merupakan vibrasi ulur dari $\mathrm{T}-\mathrm{O}(\operatorname{dimana} \mathrm{T}=\mathrm{Si}$ atau $\mathrm{Al}$ ) yang melibatkan gerakan utama dari atom oksigen. Hal yang sama juga ditegaskan oleh Madejova (2002) yang mencatat puncak serapan khas Si-O dari montmorillonit, nontronit, hektorit dan saponit berturutturutmuncul pada bilangan gelombang 1030, 1019, 1012 dan $1009 \mathrm{~cm}^{-1}$.

Munculnya punak pada bilangan gelombang $912,3 \mathrm{~cm}^{-1}$ merupakan vibrasi tekuk $\mathrm{OH}$ yang berikatan dengan kation. Serapan $754,1 \mathrm{~cm}^{-1}$ adalah serapan untuk vibrasi tekuk Si-O yang tegak lurus sumbu optik. Sedangkan puncak pada bilangan gelombang $694,3 \mathrm{~cm}^{-1}$ merupakan vibrasi tekuk $\mathrm{Si}-\mathrm{O}$ yang sejajar dengan sumbu optik. Katti (2002) juga melaporkan bahwa vibrasi tekuk $\mathrm{OH}$ dengan kation terjadi pada daerah 918, 888 dan $847 \mathrm{~cm}^{-}$ ${ }^{1}$, sedangkan puncak di bilangan gelombang $778 \mathrm{~cm}^{-1}$ adalah vibrasi tekuk Si-O yang tegak lurus dengan sumbu optik dan $671 \mathrm{~cm}^{-1}$ merupakan vibrasi tekuk $\mathrm{Si}-\mathrm{O}$ yang sejajar dengan sumbu optik.

Vibrasi tekuk Si-O-Al (Al oktahedral) muncul pada bilangan gelombang $538,1 \mathrm{~cm}^{-1}$, sedangkan $468,7 \mathrm{~cm}^{-1}$ merupakan vibrasi tekuk Si-O-Si. Menurut Komadel (2003) vibrasi tekuk Si-O-Al terjadi pada daerah serapan $520 \mathrm{~cm}^{-1}$ yang mana merupakan pita yang sangat sensitif dengan kehadiran $\mathrm{Al}$ di lapis oktahedral sedangkan Madejova (2002) mengamati vibrasi tekuk Si-O-Al terjadi pada serapan $520 \mathrm{~cm}^{-1}$ dan vibrasi tekuk Si-O-Si pada bilangan gelombang $470 \mathrm{~cm}^{-1}$.

Adanya serapan pada daerah bilangan gelombang $1629,7 \mathrm{~cm}^{-1}$ merupakan vibrasi tekuk -OH dari molekul air terserap. Hal ini sampir sama dengan yang diamati oleh Grim (1968) dalam Darwanta (2002) yang menyatakan bahwa $\mathrm{H}_{2} \mathrm{O}$ yang terserap memberikan serapan pada daerah 3400 dan $1640 \mathrm{~cm}^{-1}$ yang sesuai dengan vibrasi dari $\mathrm{H}_{2} \mathrm{O}$. Menurut Katti (2002) bahwa serapan pada 1635 $\mathrm{cm}^{-1}$ adalah vibrasi tekuk H-O-H. Munculnya serapan pada daerah bilangan gelombang 3697,3 dan 3622,1 menunjukkan adanya vibrasi ulur dari $-\mathrm{OH}$, sedangkan vibrasi pada 3431,1 $\mathrm{cm}^{-1}$ merupakan vibrasi $\mathrm{H}-\mathrm{O}-\mathrm{H}$ yang membentuk ikatan hidrogen dengan air. Hal ini juga ditegaskan oleh Madejova (2002) bahwa munculnya puncak pada bilangan gelombang 3669; 3653 dan $3620 \mathrm{~cm}^{-1}$ merupakan vibrasi ulur -OH dari silanol atau yang terdapat diantara lembaran tetrahedral dengan oktahedral, begitu juga dengan Katti (2002) melaporkan serapan pada $3634 \mathrm{~cm}^{-1}$ adalah vibrasi tekuk $\mathrm{O}-\mathrm{H}$ sedangkan pada bilangan gelombang $3433 \mathrm{~cm}^{-1}$ merupakan vibrasi H-O$\mathrm{H}$ yang membentuk ikatan hidrogen dengan air. Dapat disimpulkan bahwa kandungan utama lempung alam Tulakan Pacitan adalah montmorilonit dengan melihat adanya kesesuaian puncak-puncak pada spektra inframerah lempung alam Tulakan Pacitan 
dengan lempung montmorilonit hasil peneliti lain.

Untuk mempelajari proses yang terjadi dalam pembuatan lempung terpilar-Fe maka akan dikaji dengan spektra inframerah. Lempung hasil rekayasa dibuat dengan cara interkalasi surfaktan benzalkonium klorida dilanjutkan dengan sol-Fe pada konsentrasi yang bervariasi. Untuk melihat gugus fungsional pada lempung terinterkalasi surfaktan benzalkonium klorida dan sol besi dilakukan analisa spektrofotometer inframerah. Dari analisa ini diharapkan dapat diamati perubahan struktur dengan adanya perubahan gugus-gugus fungsional pada lempung sebagai akibat dari proses interkalasi. Dengan membandingkan hasil spektra lempung alam dan lempung terinterkalasi surfaktan dan sol besi akan diamati perubahan gugus fungsionalnya. Hasil spektrofotometernya ditampilkan pada gambar 6. Dari gambar tersebut terlihat jelas ada perbedaan yang mendasar antara spektra lempung alam Tulakan Pacitan dengan spektra lempung alam yang terinterkalasi surfaktan benzalkonium klorida dan sol besi. Perbedaan mendasar terlihat pada munculnya puncak-puncak baru pada bilangan gelombang 2925,8; 2852,5; 2381,9 dan 1458,1 $\mathrm{cm}^{-1}$. Munculnya puncak-puncak baru ini merupakan indikasi adanya sesuatu yang menyebabkan terjadinya perubahan pada struktur lempung.

Munculnya serapan pada panjang gelombang tersebut diduga berasal dari gugusgugus fungsional surfaktan benzalkonium klorida yang ditambahkan pada proses interkalasi. Serapan pada bilangan gelombang 2925,8 dan 2852,5 $\mathrm{cm}^{-1}$ merupakan daerah vibrasi ulur $\mathrm{C}-\mathrm{H}$ rantai alkil dari molekul surfaktan benzalkonium klorida. Puncak 2925,8 $\mathrm{cm}^{-1}$ merupakan daerah vibrasi $\mathrm{C}-\mathrm{H}$ simetri dari gugus $\mathrm{CH}_{2}$, sedangkan puncak 2852,5 $\mathrm{cm}^{-1}$ adalah vibrasi ulur $\mathrm{C}-\mathrm{H}$ asimetrik gugus $\mathrm{CH}_{2}$. Keberadaan gugus-gugus $\mathrm{CH}_{2}$ surfaktan ini diperkuat dengan munculnya puncak didaerah $1458.1 \mathrm{~cm}^{-1}$ yang merupakan daerah vibrasi C$\mathrm{H}$ dari deformasi $\mathrm{CH}_{2}$.

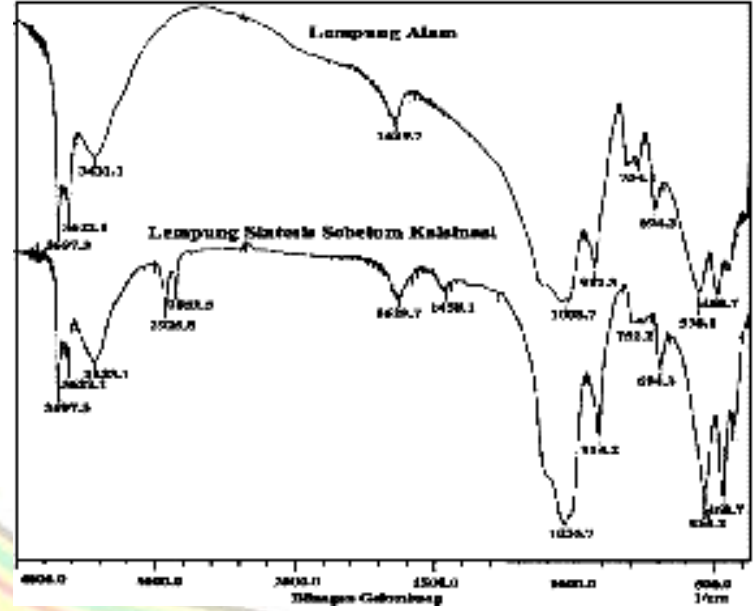

Gambar 6. Spektra lempung alam Tulakan Pacitan dan Lempung terinterkalasi surfaktan dan sol besi

Munculnya serapan pada panjang gelombang tersebut diduga berasal dari gugusgugus fungsional surfaktan benzalkonium klorida yang ditambahkan pada proses interkalasi. Serapan pada bilangan gelombang 2925,8 dan $2852,5 \mathrm{~cm}^{-1}$ merupakan daerah vibrasi ulur $\mathrm{C}-\mathrm{H}$ rantai alkil dari molekul surfaktan benzalkonium klorida. Puncak 2925,8 $\mathrm{cm}^{-1}$ merupakan daerah vibrasi $\mathrm{C}-\mathrm{H}$ simetri dari gugus $\mathrm{CH}_{2}$, sedangkan puncak 2852,5 $\mathrm{cm}^{-1}$ adalah vibrasi ulur $\mathrm{C}-\mathrm{H}$ asimetrik gugus $\mathrm{CH}_{2}$. Keberadaan gugus-gugus $\mathrm{CH}_{2}$ surfaktan ini diperkuat dengan munculnya puncak didaerah $1458.1 \mathrm{~cm}^{-1}$ yang merupakan daerah vibrasi $\mathrm{C}$ $\mathrm{H}$ dari deformasi $\mathrm{CH}_{2}$. Interkalasi surfaktan ke dalam lempung bertujuan untuk membuka rongga pada antar lapis lempung, sehingga diduga posisi surfaktan tersebut berada di antar lapis lempung. Masuknya kation $\mathrm{Fe}$ pada lempung dapat diamati pada daerah bilangan gelombang 914,2 $\mathrm{cm}^{-1}$. Pada spektra lempung hasil rekayasa sebelum kalsinasi terlihat adanya perubahan intensitas yang lebih tajam pada daerah ini. Diduga ini terjadi karena masuknya kation $\mathrm{Fe}$ pada lempung tersebut. Hal ini dipertegas oleh Katti (2002), bahwa vibrasi tekuk -OH dengan kation terjadi pada daerah bilangan gelombang 918, 888 dan $847 \mathrm{~cm}^{-1}$.

Lempung yang telah diinterkalasi dengan surfaktan benzalkonim klorida dan sol besi selanjutnya dikalsinasi sehingga terbentuk pilar oksida logam yang kaku (rigid) untuk 
menyangga struktur lapisannya. Surfaktan benzalkonium klorida merupakan spesies organik yang memiliki stabilitas termal kecil dari $400^{\circ} \mathrm{C}$. Ini dapat dilihat dengan membandingkan spektra lempung hasil rekayasa sebelum dan sesudah kalsinasi yang disajukan pada gambar 7 .

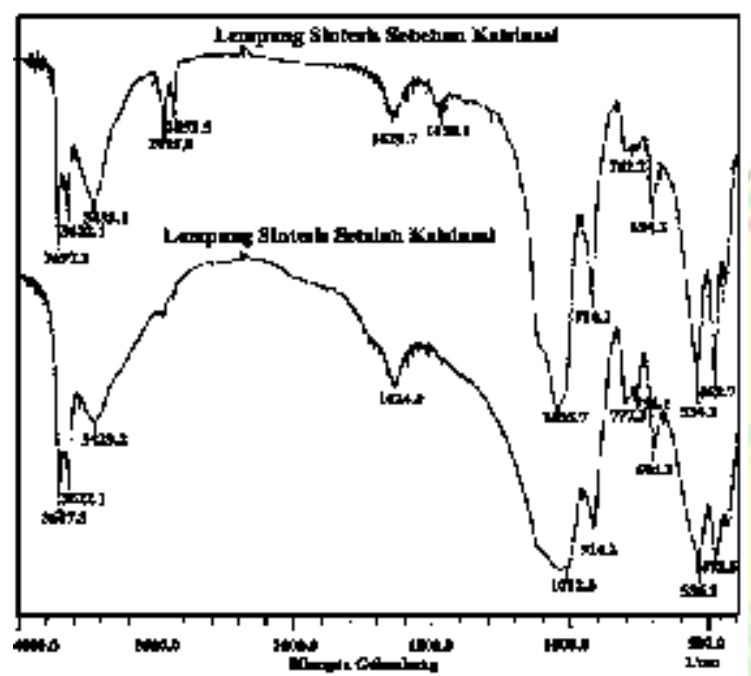

Gambar 7. Spektra lempung hasil rekayasa sebelum dan sesudah kalsinasi

Dari gambar 7. terlihat bahwa serapan khas untuk surfaktan benzalkonium klorida pada bilangan gelombang 2925,8; 2852,5; 2381,9 dan $1458,1 \mathrm{~cm}^{-1}$ setelah dikansinasi pada suhu $400^{\circ} \mathrm{C}$ tidak muncul lagi, tetapi memunculkan puncak di daerah bilangan gelombang 777,3 $\mathrm{cm}^{-1}$. Ini berarti bahwa proses kalsinasi telah menghilangkan senyawa organik dan mengubah hidrolisa besi menjadi oksida logamnya. Munculnya puncak di daerah bilangan gelombang 777,3 $\mathrm{cm}^{-1}$, menurut Madejova (2003) dan Katti dan Katti (2002), puncak ini merupakan puncak khas - $\mathrm{OH}$ yang terikat kation. Dalam hal ini kation yang diinterkalasikan adalah $\mathrm{Fe}^{3+}$ maka puncakpuncak ini diduga merupakan vibrasi $\mathrm{Fe}-\mathrm{O}$ dan Fe-OH. Sebagai akibat pilarisasi oksida logam yang terbentuk belum mampu diamati dengan spektrofotometer inframerah secara jelas. Oleh karena itu peningkatan konsentrasi $\mathrm{Fe}$ akibat terbentuknya oksida besi di dalam lempung terpilar selanjutnya akan diamati dengan metoda spektroskopi serapan atom (AAS).
2. Analisis kandungan besi dengan metoda AAS

Untuk menghasilkan lempung terpilar dengan porositas dan stabilitas termal yang tinggi, para peneliti telah mengembangkan suatu metode baru dalam sintesis lempung terpilar. Metode baru tersebut adalah dengan menginterkalasikan surfaktan kemudian diikuti dengan agen pemilar dalam sintesis lempung terpilar. Interkalasi surfaktan ionik ke dalam rongga antar lapis lempung diharapkan terjadi pembentukan pilar yang besar pada struktur lapis lempung monmorillonit, karena surfaktan berfungsi untuk membuka rongga pada antar lapis lempung sehingga kation logam mudah untuk diinterkalasi pada proses selanjutnya. Semakin besar rongga yang terbuka maka akan semakin banyak kation logam yang terinterkalasi.

Sol besi yang diinterkalasikan pada lempung berperan sebagai pilar di daerah antar lapis lempung hasil rekayasa. Pilar besi oksida ini terbentuk saat kalsinasi. Jumlah sol besi yang masuk di daerah antar lapis akan menentukan jumlah besi oksida yang terbentuk. Untuk mengetahui peranan surfaktan dalam pengaturan jumlah sol besi yang masuk di dalam lempung maka akan dikaji kandungan besi pada lempung dengan spektrofotometer serapan atom. Adapum besarnya jumlah surfaktan yang diinterkalasikan untuk masingmasing sampel yaitu $0.1 \%, 1 \%, 5 \%$ dan $10 \%$. Hasil analisis kandungan besi pada lempung alam dan lempung hasil rekayasa disajikan pada tabel 1 dan gambar 8 .

Dari tabel 1 terlihat bahwa proses interkalasi sol besi dapat dikatakan telah berlangsung dengan sukses. Hal ini dapat dilihat dengan membandingkan kandungan besi pada lempung alam dengan kandungan besi yang diinterkalasi dengan sol besi telah terjadi peningkatan yaitu dari $22,849 \mathrm{mgr} / \mathrm{gr}$ menjadi 47,713 $\mathrm{mgr} / \mathrm{gr}$ atau terjadi kenaikan sekitar 77.43\%. Penambahan surfaktan pada konsentrasi $1 \%$ merupakan kondisi optimum untuk masuknya sol besi ke dalam lempung lempung hasil rekayasa. Ketika penambahan surfaktan di atas $1 \%$ yaitu sekitar 5\% dan $10 \%$ 
maka jumlah sol besi di dalam lempung lempung hasil rekayasa semakin sedikit. Terlihat bahwa konsentrasi surfaktan membatasi jumlah sol besi yang bisa masuk ke daerah antar lapis lempung. Dengan kata lain terjadi kompetisi antara sol besi dan molekul surfaktan.

Surfakatan yang diinterkalasikan ternyata berpengaruh terhadap jumlah besi oksida yang terbentuk. Semakin tingginya konsentrasi surfaktan yang diinterkalasikan akan semakin sedikit jumlah besi oksida yang masuk pada lempung hasil rekayasa. Masuknya surfaktan dapat mengarahkan masuknya sol besi ke daerah antar lapis lempung. Penambahan surfaktan ini bertujuan untuk membuka rongga pada antar lapis lempung sehingga mudah untuk diinterkalasi lebih lanjut dengan kation logam. Tampaknya pada kondisi ini sol besi dan molekul surfaktan secara bersama-sama optimal mengisi daerah antar lapis lempung. Namun penataan keduanya pada daerah antar lapis dikontrol oleh sol surfaktan.

Pada saat konsentrasi surfaktan dinaikan menjadi 5\% dan 10\%, konsentrasi surfaktan cukup besar sehingga memungkinkan molekul surfaktan berkompetisi lebih besar untuk menata diri didaerah antar lapis. Masuknya surfaktan dengan konsentrasi cukup tinggi ini mampu menghambat sebagian sol besi sehingga konsentrasi sol besi menjadi turun.

Tabel 1. Kandungan besi pada lempung alam dan lempung hasil rekayasa

\begin{tabular}{|c|c|c|c|c|}
\hline \multirow[t]{2}{*}{ Adsorben } & \multirow{2}{*}{$\begin{array}{c}\text { Konsentrasi surfaktan BKC } \\
\text { yang ditambahkan }\end{array}$} & \multirow{2}{*}{$\begin{array}{c}\text { Jumlah Fe yang } \\
\text { ditambahkan } / \mathrm{gr} \\
\text { lempung }\end{array}$} & \multicolumn{2}{|c|}{ Kandungan besi } \\
\hline & & & (mgr/gr) & $\begin{array}{l}\text { \% berat } \\
\text { (mgr/gr) }\end{array}$ \\
\hline Lempung alam & 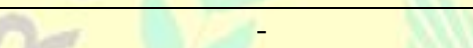 & - & 22,849 & 2,28 \\
\hline $\begin{array}{l}\text { Adsorben }-1 \\
\text { Adsorben }-2 \\
\text { Adsorben }-3 \\
\text { Adsorben }-4\end{array}$ & BKC $0,1 \%$ & $\begin{array}{l}0,0875 \mathrm{gr} \\
0,6130 \mathrm{gr} \\
1,1385 \mathrm{gr} \\
1,6640 \mathrm{gr}\end{array}$ & $\begin{array}{l}25,939 \\
35,455 \\
44,966 \\
43,238\end{array}$ & $\begin{array}{l}2,59 \\
3,55 \\
4,50 \\
4,32\end{array}$ \\
\hline $\begin{array}{l}\text { Adsorben }-5 \\
\text { Adsorben }-6 \\
\text { Adsorben }-7 \\
\text { Adsorben }-8\end{array}$ & BKC $1 \%$ & $\begin{array}{l}0,0875 \mathrm{gr} \\
0,6130 \mathrm{gr} \\
1,1385 \mathrm{gr} \\
1,6640 \mathrm{gr}\end{array}$ & $\begin{array}{l}30,101 \\
40,599 \\
47,713 \\
46,591 \\
\end{array}$ & $\begin{array}{l}3,01 \\
4,06 \\
4,77 \\
4,66\end{array}$ \\
\hline $\begin{array}{c}\text { Adsorben }-9 \\
\text { Adsorben }-10 \\
\text { Adsorben }-11 \\
\text { Adsorben }-12 \\
\end{array}$ & BKC 5\% & $\begin{array}{l}0,0875 \mathrm{gr} \\
0,6130 \mathrm{gr} \\
1,1385 \mathrm{gr} \\
1,6640 \mathrm{gr}\end{array}$ & $\begin{array}{l}24,762 \\
29,713 \\
33,310 \\
32,410 \\
\end{array}$ & $\begin{array}{l}2,48 \\
2,97 \\
3,33 \\
3,24 \\
\end{array}$ \\
\hline $\begin{array}{l}\text { Adsorben - } 13 \\
\text { Adsorben - } 14 \\
\text { Adsorben - } 15 \\
\text { Adsorben - 16 } \\
\end{array}$ & BKC $10 \%$ & $\begin{array}{l}0,0875 \mathrm{gr} \\
0,6130 \mathrm{gr} \\
1,1385 \mathrm{gr} \\
1,6640 \mathrm{gr}\end{array}$ & $\begin{array}{l}24,804 \\
26,227 \\
29,089 \\
28,137\end{array}$ & $\begin{array}{l}2,48 \\
2,62 \\
2,91 \\
2,81 \\
\end{array}$ \\
\hline
\end{tabular}

Kandungan Fe di dalam lempung alam dan hasil rekayasa

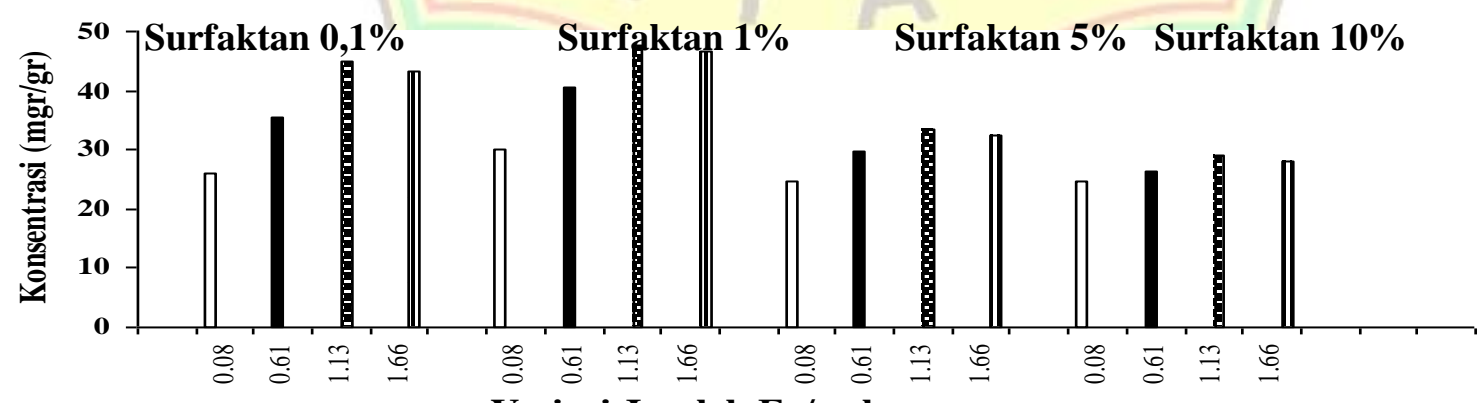

Gambar 8. Grafik kandungan Fe dia dalamplempung atam dan lempung hasil rekayasa

\section{KESIMPULAN}

Hasil penelitian menunjukkan bahwa proses pillarisasi dengan menginterkalasikan
$\mathrm{FeCl}_{3} .6 \mathrm{H}_{2} \mathrm{O}$ dapat meningkatkan kandungan besi oksida hingga sebesar lima kali lipat bergantung pada rasio mol $\mathrm{Fe}$ dan nilai kapasitas pertukaran 
kation (KTK) bentonit alam. Dari data spectra infra merah (FT-IR) dapat disimpulkan bahwa interkalasi surfaktan pada ruang antar lapis silikat dapat teramati dengan adanya puncak pada bilangan gelombang 2825,8 dan 2852,5 $\mathrm{cm}^{-1}$, sedangkan pilar besi oksida tidak teramati

\section{DAFTAR PUSTAKA}

Badan POM RI, 2004, Persyaratan Penggunaan Bahan Tambahan Pangan Pemanis Buatan dalam Produk Pangan, Jakarta

Clearfield, Abraham, 1992, "Preparation of Pillared Clays and Their Catalytic Properties", Chemistry Departement Texas A and M University College Station, 345-390.

Cool, P., and Vanssant, E.F., 1988, “Pillared Clays: Preparation, Characterization and Aplication “, Moleculer Sieves, Springer.

Darwanta, 2002, "Sintesis dan Karakterisasi Lempung Terpilar-Al Serta Aplikasinya Sebagai Katalis Hidrorengkah Fraksi Berat Minyak Bumi”, Tesis S-2, Universitas Yogyakarta.

Flanigen, E.M., Khatami, H., 1971, "Infrared Structural Studies of ZeoliteFramework, Molecullar Sieve Zeolite-I", American Society Adv. In Chemistry Series No. 101, Washington, 201-226.

Grim R.E., 1968", Clay Mineralogy", second Edition, Me Graw Hill Book Company, New York.

Gunzler, H., Gremlich, H., 2002, “ I R Spektroscopy “, Wiley-VCH, Germany.

Katti,K., and Katti D., 2001, "Effect of ClayWater Interactions on Swelling in Montmorillonite Clay", Departement of Civil Engineering and Construction North Dakota State University, Fargo.

Komadel, P., 2003, "Chemically Modified smectites", Slovac Academy of Sciences, Slovakia, Clay Mineral, 38, 127 -138

Kwon, O., Park, K., and Jeong, S., 2001, "Preparation of porous Silica-Pillared Monmorillonite: Simultaneous Intercalation of Amine-Tetraethylortho- silicate into H-Montmorillonite", Bull. Korean Chem. Soc., 22, 678-684.

Madejova, J., 2003, "FTIR Techniques in Clays Mineral Studies", Slovac Academy of Sciences, Slovakia, 31, 1 - 10.

Ogawa, M. and Kuroda, K., 1997, "Preparation of Inorganic Nanocomposites through Intercalation of Organoammonium Ions into Layered Silicates", Bull. Chem. Soc. Jpn., 70, 2593-2618.

Polverejan, M., Pauly, T. R., and Pinnavaia, T. J., 2000, Acetic Porous Clay Heterostructure ( $\mathrm{PCH})$ : Intragallery Assembly of mesoporous Silica in Synthetic Saponite Clay, Chem. Mater., 12, 2698-2704

Pinnavaia, T.J., 1983, "Intercalated Clay Catalyst", Science, 220 - 365.

Pinnavaia, T.J., Galarneau, A. H., and Barodawalla, A. F., 1998, "Porous Clay Heterostructure by Gallery Templated Synthesis", United State Patent, 5, 834391.

Rightor, E.G., Tzou, M.S., and Pinnavaia, T.J., 1991, " Iron Oxide Pillared Clay with Large Gallery Height: Syntesis and properties as a Fischer - Tropsch Catalyst, Journal of Catalysis, 130, 29 40.

Riyanto, A., 1994, “ Bahan Galian Industri Bentonit”, Direktoral Jendral Pertambangan Umum, Pusat Penelitian dan Pengembangan Teknologi Mineral, Bandung.

Yang, R.T., Chem, J.P., Kikkinedes, E.S., and Cheng, L.S., 1992, Pillared Clay as Superior Catalyst for Selective Catalytic Reduction of NO with NH3", Ind. Eng. Chem. Res., 31, 1440 - 1445

Wijaya, Karna, 2000, "Sintesis Lempung Monmorilonit Terpilar Berbahan Baku Bentonit Alam Indonesia dan Aplikasinya Sebagai Katalis, Bahan Foto-Fungsional dan Adsorben", Universitas Gadjah Mada, Yogyakarta. 